\title{
Knowledge Level of Medicinal Plant Utilization and Conservation Efforts of Communities around Nature Conservation Areas in Central Sulawesi
}

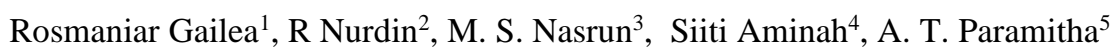 \\ \{gailearos@gmail.com\} \\ Faculty of Agriculture, Universitas Muhammadiyah Palu, Jl.HangTuah No 114 Central Sulawesi
} 94118, Indonesia

\begin{abstract}
Central Sulawesi has Natural Conservation Areas (NCA). People who lived around the NCA certainly have local wisdom regarding their daily lives, including knowledge on the use of medicinal plants. This research aims to determine the level of local knowledge of the community based on its utilization and conservation aspects. The percentage of people over 40 years old $80 \%$ and people under 40 years old have the lowest knowledge level of 20 . The method used was semi-structured interviews and direct observation of the community's existence of medicinal plants. Determination of respondents was conducted through purposive sampling. The number of respondents involved was 90 people, 30 in each village. The number of medicinal plant species obtained in the Poboya Village is 46 types, 57 types in Mataue Village, and 62 types in Bobo Village. The aspect of preservation of medicinal plants by the community is following the use of medicinal plants that they do that still have a sustainable nature, and this is indicated by the use of parts of medicinal plants, the highest utilization is leaves (61\%), most of the habitus is herbs (54\%), and The habitat where the medicinal plants are obtained is in the yard (59\%).
\end{abstract}

Keywords: Knowlegde, Medicinal Plant, utilization, Conservation

\section{Introduction}

Central Sulawesi Province is the largest province in Sulawesi Island, and forest coverS approximately $64.60 \%$ of the total area of Central Sulawesi Province. Protected areas include Nature Reserve Areas and Nature Conservation Areas (land and waters), covering 676,248 hectares or $(9.94 \%)$ of the total forest area [1]

The Nature Conservation Areas (NCA) in this study are the Lore Lindu National Park (LLNP) and the Forest Park (Taman Hutan Raya/Tahura) Palu. NCA is an area with specific characteristics. Both land and water have the primary function of protecting life support systems, preserving plant and animal diversity, and using biological natural resources and their ecosystems. [2]

People around The NCA, the LLNP, and Grand Forest Park Palu have lived there or generations, long before establishing these protected areas. The majority of the people around LLNP are the Kaili Tribe, the most significant indigenous in Central Sulawesi, Kaili Moma 
(Kulawi), and the Pekurehua Tribe of Tara ethnic from Lore sub-district Poso District and other immigrant tribes such as the Bugis-Makassar, Toraja, Minahasa, Javanese. People around Forest Park Palu, in general, are the Kaili Tara Tribe / Sub-ethnicity and other tribes.

They have local wisdom in living their lives in general, one of which is through various types of plants that have been used for traditional medicine for generations. The community can do treatment of various types of diseases and health care using traditional plants. [3]

Previous studies have found that the recognition of indigenous, local, and traditional knowledge systems has increased knowledge of ecosystems, natural resources, and biodiversity [4] From the knowledge and use of plants by the community, it can be seen that the aspects of preservation of these types of medicinal plants do not interfere the plant growth compared to using roots, for example when people tend to use more leaves than other plant parts to treat various types of diseases, stem or bark. However, the use of plant parts for traditional medicine also depends on natural conditions, the environment, and local natural resources availability.

Activities to explore or reveal local/traditional knowledge continue in several countries, not only in Indonesia. [5] The use of medicinal plants is essential in Southeast Asia, where biology and enormous cultural diversity illustrate the diversity of traditional medicine systems.

Based on these descriptions, it is necessary to conduct research on local community knowledge, utilization and conservation efforts that have been carried out. This research aims to determine the level of local knowledge of the community based on its utilization and conservation aspects

\section{Method}

This research was conducted in Poboya, Mataue, and Petimbe. Poboya is an administrative area on the boundary of the Grand Forest Park of Palu, while Mataue and Petimbe are administrative areas located around Lore-Lindu National Park. The research was conducted in September 2017 - March 2018.

The selection of research areas was carried out purposively by considering the areas directly adjacent to the natural conservation areas. The materials and tools used in the study included a set of field tools for collecting herbarium specimens. medicinal plant specimens for herbarium collections, and questionnaire lists for the use of medicinal plants by the community.

The determination of the respondents to collect data on public knowledge about the use of traditional medicinal plants was done by purposive sampling by considering the age criteria of the people who used traditional medicinal plants. The criteria used in the age classification of the respondents consisted of people aged: 1)> 40 years old, and 2) <40 years old. The number of respondents in each village consisted of 30 people, so that overall in the study there were 90 respondents.

The data was collected through a semi-structured interview method using a questionnaire. Furthermore, based on the results of the interview, specimens of medicinal plants that have been used by the community were collected. Preparation of medicinal plant specimens is used for herbarium identification and collection. The identification of medicinal plant species was carried out at the Herbarium Celebense laboratory, Tadulako University. 
Descriptive statistics are used for data analysis of observation parameters which include: 1) age of medicinal plant users, 2) number of medicinal plant species used by the community, 3) parts of plants used, 4) habitus, 5) habitat.

\section{Result and Discussion}

\subsection{Nature Conservation Areas in Central Sulawesi}

Forest Park of Central Sulawesi is one of the nature conservation areas (NCA) confirmed by Ministerial Decree No.24 / Kpts-II / 1999 covering an area of 7,128 ha, is an amalgamation of Poboya Nature Reserve, Paneki Protected Forest, and Kapopo Nature Park (the location of the National Green Week 30). Administratively, this includes Palu City and Donggala Regency; from the beginning, the management was carried out unilaterally of one side without involving other parties, including the community and customary institutions in/around the area.[6]

LLNP has essential meaning for protecting ecosystems and life support systems to the diversity of flora and fauna. Fauna, LLNP is also a source of livelihood for the surrounding community. [7] Furthermore, [8] stated that the motivation of people around LLNP is based on material needs. The motivation of the need for traditional medicines and wood to build materials and tools also classified as high

Forest Park and the Lore Lindu National Park (LLNP) are The Nature Conservation Areas (NCA) in Central Sulawesi where the local life there came from various tribes/ethnicities, such as Kulawi and Pekurehua tribes but dominated by the Kaili Tribe, which has quite a lot of sub-ethnic groups and are indigenous tribes in Central Sulawesi.

\subsection{Knowledge of Medicinal Plants}

People in various parts of the world have used traditional knowledge through resources provided by nature to prevent, diagnose, treat health problems long before the development of pharmacy [9]

The people of Poboya, Mataue, and Petimbe Villages have almost the same knowledge of the types of medicinal plants and their benefits. In general, public knowledge about medicinal plants and traditional medicine comes from their parents who have been passed down from generation to generation; Healer generally has a higher level of knowledge than the general public. However, the percentage is not too different, as in Table 1.

Table 1.The level of community knowledge about medicinal plants around NCA

\begin{tabular}{cc}
\hline Level of Knowledge & Total (\%) \\
\hline Age $\geq 40$ & 80 \\
Age $\leq 40$ & 20 \\
\hline
\end{tabular}


The level of knowledge and the utilization of medicinal plant species of people in Poboya Village is lower than people in Petimbe and Mataue Villages. Poboya Village is located around Forest Park Palu, as one of the NCA. Forest Park Palu has a relatively high biodiversity of lowland forest. In the last ten years, the Forest Park area, especially in the Poboya sub-district, has experienced quite heavy pressures on the environment due to gold mining.

In connection with the knowledge of medicinal plants and traditional medicine, people around LLNP (Mataue Village and Petimbe Village) still use various types of medicinal plants taken in gardens, yards, and harvest from the forest. This is in line with the results of Massiri's (2016) [8] that the motivation for the need for traditional medicines is classified as having high motivation in the community around LLNP.

The community around LLNP is maintaining and practicing knowledge of traditional medicine using ingredients from plants. Although it is suspected that there has been a shift in knowledge and the use of medicinal plants as an alternative to modern medicine and the improvement of health facilities from the government, the community has not entirely abandoned the treatment pattern.

Apart from the issue of modernization in medicine, in Malaysia, a modern generation who do not want to know or practice their ancestors' deeds is also the leading cause of the loss of practice and knowledge of traditional care today. [10]

A decrease in medicinal plants' use has also occurred in Kenya, Africa [11]. There has been a difference between knowledge and medicinal plants in the Marakwet community in Kenya; this shows the possibility of erosion of local wisdom in the community. In the Ngunnawal and Yuin communities in Australia, knowledge of traditional food and medicinal plants still exists. However, the lack of involvement of young people is a problem in itself. [12]

\subsection{Number of Types of Medicinal Plants Known to the Community}

Until 2007, The Laboratory of Medicinal Plant Conservation, Faculty of Forestry, Bogor Agricultural Institute, has collected approximately 2039 species of medicinal plants originating from Indonesia forest. Therefore, Indonesia is one of the most important storehouses of biodiversity in the world [3]

Ethnobotany and ethnopharmacological studies have been carried out quite a lot, especially around the TNLL area [12-13-14]. There are 105 species of medicinal plants known and used in Peboya Village, Mataue Village, and Petimbe Village.

\subsection{Preservation of Medicinal Plants according to their utilization by the community around the Nature Conservation Area}

\subsubsection{Part of medicinal plants used}

Parts of medicinal plants widely used by the people around the NCA are leaves $(61 \%)$, flowers (13\%), fruit 96\%), seeds $4 \%$ ), stems (5\%), roots (3), tubers (5\%), whole plant 3\%). Leaves are the most used ones. The use of leaves for traditional medicine is in three places, or $61 \%$. The use of leaves as traditional medicine is relatively safer viewed through the preservation of medicinal plants because it does not interfere with plant growth compared to the use of other plant parts such as roots, stems, and bark. In general, leaves are partPart of the 
plant that is mostly used by the people around LLNP [3-16-15]. Harvesting the roots and utilizing all parts of the plant will be more destructive than plant parts such as leaves, flowers, or buds. [17]

\subsubsection{Habitus}

Habitus or common forms of plants include trees (195), shrubs (95), bush (7\%), lianas (7), and herbs $(54 \%)$, most widely used by the community than other habitus. The use of herbal habitus as traditional medicine reaches $54 \%$ or 57 species. The aspect of preserving medicinal plants assumed that medicinal plant species from the herbal habitus are relatively safer than the tree or shrubs.

\subsection{Preservation of Medicinal Plants by Communities around Nature Conservation Areas}

The Lore Lindu National Park (LLNP) and Forest Park Palu have issues related to the surrounding communities' existence. These problems include population growth, which, of course, will affect the need for clothing, shelter, and food. This demand will undoubtedly encourage the community to carry out land clearing, encroachment, etc. It is likely that the life of biodiversity, including medicinal plants that grow in or around the NCA, will be threatened.

A threat to the notable wild species, particularly for food and medicine, is the overharvesting, habitat, and climate change.[18]. Communities around The Lore Lindu National Park (LLNP) (Petimbe Village and Mataue Village) are still collecting medicinal plants. This was also expressed by [8],that people around LLNP have a high demand for traditional medicines. Meanwhile, people in the Forest Park Palu Area (Poboya Urban Village), in which the opening of gold mining causes a reduction in biodiversity, including the bio-medicinal plants.

Medicinal plants are found in yards, gardens, forests, rice fields, swamps, wild (along roads, ditches, graves, etc.) in these three villages (Poboya Village, Mataue Village, and Petimbe Village). 62 species or 59\% of medicinal plants are found living in the yard, and it is the place where most medicinal plants are found.

Table 2. The types of medicinal plants in the yard

\begin{tabular}{lll}
\hline No & \multicolumn{1}{c}{ Scientific name } & \multicolumn{1}{c}{ Family } \\
\hline 1. & Abelmoschus moschatus L. & Malvaceae \\
2. & Abrus procatorius L. & Papilionaceae \\
3. & Acalypha indica L. & Verbenaceae \\
4. & Aglaia odorata Lour & Euphorbiaceae \\
5. & Acalypha sp & Euphorbiaceae \\
6. & Alternanthera ficoides R.B. & Amaranthaceae \\
7. & Aloe vera (L.) Webb & Liliaceae \\
8. & Alpinia galangan $(\mathrm{L})$ Swartz. & Zingiberaceae \\
9. & Alpinia sp. & Zingiberaceae \\
10. & Amaranthus spinosus L. & Amaranthaceae \\
11. & Andrographis paniculata Burm. f. & Acanthaceae \\
12. & Andropogon nardus L. & Poaceae \\
13. & Annona reticulate L. & Annonaceae
\end{tabular}


14. Arcangeliisia flava L.(Merr.)

15. Areca catechu $\mathrm{L}$.

16. Areca sp.

17. Areca vestiaria Giseke

18. Artemisia vulgaris $\mathrm{L}$

19. Arthocarpus communis J.R.\& G.Frost.

20. Arthocarpus heterophylla Lamk.

21. Averrhoa bilimbi L.

22. Blumea balsaminifera (L) DC

23. Biophytum reinwardtii (Zucc.) Klotz.Sch.

24. Centella asiatica Urb.

25. Citrus aurantifolia (Christm \&Panz) Swingle

26. Clerodendrum calamitous L.

27. Cinnamomum zeylanicum $\mathrm{B} 1$.

28. Cirus aurantifolia Swingle

29. Coleus scutellarioides Bth,

30. Curcuma aeroginosa Roxb.

31. Curcuma xanthorrhiza

32. Curcuma zedoaria (Berg.)Roscoe

33. Cyperus rotundus L.

34. Dysophylla auricularia (L.)Blume

35. Erigeron sumatraensis Retz

36. Euphorbia hirta L.

37. Gynura procumbens

38. Grapthophyllum pictum Griff.

39. Helianthus annum L.

40. Heliconia indica Lamk.

41. Ipomoea reptans Poir

42. Jatropha curcas L.

43. Jatropha multifida L.

44. Justicia gandarussa Burm $\mathrm{f}$.

45. Kalanchoe pinnata Pers.

46. Lannea coromandeica (Houtt.) Merr.

47. Moringa oleifera Lamk.

48. Ocimum basilicum L.

49. Orthosiphon spicatus BBS.

50. Pedilanthus tithymaloides (L.) Poit

51. Piper betle L.

52. Plantago mayor $\mathrm{L}$.

53. Punica gratum L.

54. Phyllanthus urinaria L.

55. Ricinus communis $\mathrm{L}$.

56. Sigesbeckia orientalis L

57. Svernonia cinerea $S w$.

58. Tabernaemontana pandacaqui Poir.

59. Tinospora crispa (L.) Miers.

60. Tridax procumbens L.

61. Zingiber cassumunar Roxb.
Menispermaceae

Arecaceae

Arecaceae

Asecaceae

Asteraceae

Moraceae

Moraceae

Oxalidaceae

Asteraceae

Oxalidaceae

Umbelliferae

Rutaceae

Verbenaceae

Lauraceae

Rutaceae

Lamiaceae

Zingiberaceae

Zingiberaceae

Zingiberaceae

Graminae

Lamiaceae

Asteraceae

Euphorbiaceae

Compositae

Rubiaceae

Asteraceae

Heliconiaceae

Convolvulaceae

Euphorbiaceae

Euphorbiaceae

Acanthaceae

Crassulaceae

Anacardiaceae

Moringaceae

Lamiaceae

Labiatae

Euphorbiaceae

Piperaceae

Plantaginacea

Punicaceae

Euphorbiaceae

Euphorbiaceae

Crassulaceae

Asteraceae

Apocynaceae

Menispermaceae

Asteraceae

Zingiberaceae 
The medicinal plants in the yard grow by people to take them quickly when the medicinal plants are needed. Meanwhile, Cultivation efforts on a broader scale have not been carried out. The preservation of medicinal plant species by the community in their yards is a first step in preserving medicinal plants both around LLNP and around Forest Park Palu.

There are 6 species of plants in Table 1 that grow in forests and are rarely found, these plants are Alpinia sp, Archangelisia flava (L.) Merr., Areca sp, Areca vestiaria Giseke, Graphtophyllum pictum Griff., Tinospora crispha (L.) Miers.

\section{Conclusion}

The communities around The Lore Lindu National Park (LLNP) and Grand Forest Park conversant about medicinal plantsfor traditional medicine. The percentage of people over 40 years old $80 \%$ and people under 40 years old have the lowest knowledge level of 20 . There are 105 medicinal plants used by the community in the study area. The parts of medicinal plants that are widely used by the community consecutively include: leaves $(61 \%)$, flowers (13\%), fruit $(6 \%)$, seeds $(4 \%)$, stem $(5 \%)$, root $(3 \%)$, tuber $(5 \%)$ and whole plant $(3 \%)$. The habitus of medicinal plants that are most widely used by the community, respectively, include: herb (54\%), shrub (9\%), bush (7\%), tree (19\%). The dominant medicinal plant habitats used by the community are in the house yard $(59 \%)$, forest $(19 \%)$, rice fields $(9 \%)$, swamps $(4 \%)$. The efforts to conserve medicinal plants that have been carried out by the community ex-situ include Alpinia sp, Archangelisia flava (L.) Merr., Areca sp, Areca vestiaria Giseke, Graphtophyllum pictum Griff., Tinospora crispha (L.) Miers.

\section{References}

[1] Central Sulawesi District Data for Selecting DA Sites.

[2] PP no, 108 Tahun 2015. 2015.

[3] Gailea R, Bratawinata AA, Pitopang R, Kusuma IW. The use of various plant types as medicines by the local community in the enclave of the Lore-Lindu National Park of Central Sulawesi, Indonesia. Glob J Res Med Plants Indig Med [Internet]. 2016;5(1):29-40.

[4] Markkula I, Turunen MT, Kantola S. Traditional and local knowledge in land use planning: Insights into the use of the Akwé: Kon guidelines in Eanodat, Finnish Sápmi. Ecol Soc. 2019;24(1).

[5] Srithi K, Trisonthi C, Wangpakapattanawong P, Balslev H. Medicinal plants used in Hmong women's healthcare in northern Thailand. $J$ Ethnopharmacol. 2012;139(1):119-35.

[6] Lahandu J, Tarumingkeng RC, Kartodihardjo H. Analisis Kebijakan Pengelolaan Akses Sumber Daya Alam oleh Masyarakat Kaili di Tanah Hutan Raya (Tahura) Sulawesi Tengah. J Agrisains. 2016;17(April):24-33.

[7] Maiwa A, Umar S, Rahman A, Kehuutanan J, Kehutanan F, Tadulako U. Resolusi konflik dalam pengelolaan taman nasional lore lindu. 2018;6(2011):47-54.

[8] Massiri SD, Nugroho B, Kartodihardjo H, Soekmadi R, Dramaga KIPB. Preferensi Dan Motivasi Masyarakat Lokal Dalam Pemanfaatan Sumberdaya Hutan Di Taman 
Nasional Lore Lindu, Provinsi Sulawesi Tengah. $J$ Mns dan Lingkung. 2016;23(2):215-23.

[9] Barata AM, Rocha F, Lopes V, Carvalho AM. Conservation and sustainable uses of medicinal and aromatic plants genetic resources on the worldwide for human welfare. Ind Crops Prod. 2016 Oct 15;88:8-11.

[10] Akhiar SKB. Amalan Dan Penggunaan Herba Dalam Perubatan Tradisional Melayu Selepas Bersalin Di Zon Tengah, Semenanjung Malaysia. Sist perubatan Altern. 2013;1-3.

[11] Wanjohi BK, Studio V, Njenga EW, Kipkore WK. An Ethnobotanical Study of Traditional Knowledge and Uses of Medicinal Wild Plants among the Marakwet Community in Kenya. Evidence-based Complement Altern Med. 2020;2020.

[12] Heaney E, Sutherland S, Bell T, Unit IH. KNOWLEDGE AND USE OF TRADITIONAL PLANTS BY NGUNNAWAL AND YUIN PEOPLE OF AUSTRALIA : BARRIERS TO KNOWLEDGE AND TRANSMISSION. 2020;1(July 2019):52-95.

[13] Kissinger, Zuhud EA, K L, Darusman, Iskandar. Potensi Hutan Tropika Indonesia Sebagai Penyangga Bahan Obat ( The Indonesian Tropical Forest As Buffer Of Natural Medicine Product For Nation Healthy ) The Indonesian Tropical Forest Producing The Medicinal Plants Diversity As Useful For Human Healthy. J Penelit Has Hutan. 2015;31(1):9-18.

[14] Susiarti S, Purwanto Y, Windadri F. Pengetahuan Masyarakat Pekurehua di Sekitar Taman Nasional Lore Lindu. Media Penelit dan Pengembang Kesehat. 2009;XLX(4):185-92.

[15] Arham S, Khumaidi A, Pitopang R. "Keanekaragaman jenis tumbuhan obat tradisional dan pemanfaatannya pada suku kulawi di desa mataue kawasan taman nasional lore lindu." J Biocelebes. 2016;10(2):01-16.

[16] Gailea R, Pitopang R, Palu UM. Di Kecamatan Lindu Kabupaten Sigi. 2016;64-9.

[17] Chen SL, Yu H, Luo HM, Wu Q, Li CF, Steinmetz A. Conservation, and sustainable use of medicinal plants: Problems, progress, and prospects. Chinese Med (United Kingdom). 2016;11(1):1-10.

[18] Romanelli, Cristina, Cooper, David, Campbell-Lendrum, Diarmid, Maiero, Marina, Karesh, William B., Hunter, Danny, Golden CD. Connecting Global Priorities: Biodiversity and Human Health, a State of Knowledge Review. World Heal Organ Secr Conv Biol Divers [Internet]. 2015;360pp. 